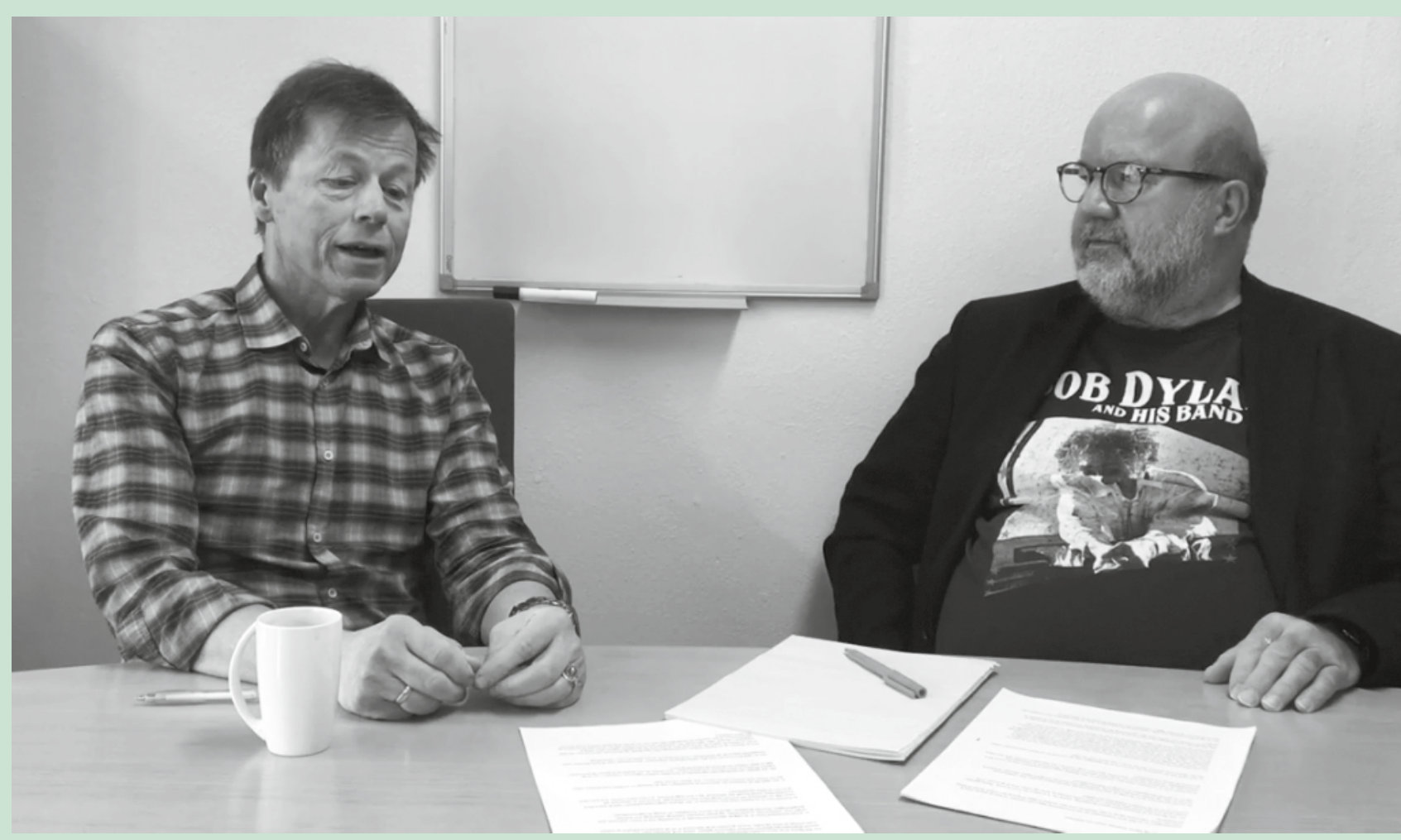

Fra venstre: Lars Mehlum og Kim Larsen.

\title{
Mannens språk - om suicidalitet og kjønnsforskjeller
}

\author{
Intervju med Lars Mehlum
}

\section{Av Kim Larsen og Hanne Holmesland}

Suicidologisk forskning har funnet en del konsistente kjønnsforskjeller. La oss starte med å utforske disse nærmere og se hvilke faktorer som kan tenkes å ligge til grunn for dem. For det forste er jo selvmordsforekomsten svært forskjellig, ca. 3-4 menn for hver kvinne. Denne disproporsionaliteten mellom kjønnene gielder (med små unntak) stort sett overalt $i$ verden med unntak av Kina og India. Hva er grunnen til at selvmord er et så markert maskulint prosiekt?

- Det er naturlig å tenke at en slik tverrkulturelt forekommende kjønnsforskjell ikke bare har med kultur, men også med biologi å giøre - det er åpenbare forskjeller på menn og kvinner. På tvers av kulturer ser det ut til at kvinner i større grad verbaliserer og bruker sosiale mestringsstrategier i møte med emosjonelle vanskeligheter. De knytter seg til andre, de tar kontakt og ber om støtte eller de uttrykker hvordan de har det, mens menn giennomsnittlig og på mange vis har færre av de sosiale mestringsferdighetene. Menn ser ut til å være mer avhengig av instrumentell mestring, dvs. giøre ting, fysisk, eller giennom en form for oppgaveløsning. Dette er ett av de paradoksene og problemene vi fortsatt sliter med - veldig få selvmordsforebyggingsprogrammer tar høyde for denne forskjellen mellom menn og kvinner.

\section{Metoder}

Et annet konsistent funn er at valg av selvmordsmetode er forskjellig ved at menn statistisk sett velger mer voldsomme, mutilerende og letale metoder (skyting, utsprang) enn kvinner (forgiftninger). Hva kan årsakene være? Er denne forskjellen et utslag av kjonnsrollene, kan du si noe om disse valgene?

- Vi har lite sikker viten om dette. Likevel vet vi at menn giennomsnittlig viser mer aggressiv og voldelig atferd enn kvinner, og dette kan trolig 
forklare noe av forskjellene. Menn har også, i vårt land, giennomsnittlig mer kunnskap om og tilgang til skytevåpen og slike faktorer vet vi betyr mye for forekomsten av selvmord ved den spesifikke metoden. Så kan vi tenke oss at menn er mer handlingsorienterte og kanskje mer kompromissløse og derfor velger mer drastiske metoder, mens kvinner kanskje gir livet litt flere sjanser, men dette vet vi mindre om.

\section{Forsøk}

Et forhold som er omfattet med stor interesse er det såkalte «kjønnsparadokset»: Mens flere menn dor av selvmord har kvinner langt flere selvmordsforsøk. Hva kan være grunnen til dette?

- Totaltallet av selvmordskriser som fører til selvmordshandling er høyere blant kvinner, de velger ofte mindre farlige metoder, slik vi har vært inne på, og dette er handlinger som man lettere overlever og man får en ny sjanse. Jeg tror ikke det er tilfeldig at kvinner giennomsnittlig velger slike metoder. Det gielder ikke bare selvmordshandlinger. Det gielder også annen type atferd. Kvinner tar i mye mindre grad risiko og sjanser, setter i mindre grad livet på spill, garderer seg mer - det gielder kvinner både med og uten barn. Noe av dette er antakeligvis kulturelt betinget, mens annet handler om biologiske faktorer . Kanskie er det en genetisk programmert egenskap for kvinner å være mer opptatt av livet, å beskytte seg selv og livet. Tenke framover. Og jeg tror det samme gielder motsatt for menn. Biologisk, men også kulturelt, blir gutter fortsatt sosialisert inn til å ta sjanser, være mer modige, pågående og aggressive - med alle de variasioner som gielder fra familie til familie og menneske til menneske, naturligvis.

\section{Suicidale prosesser}

Er det slik at motivene for selvmord er forskjellige? leg så nettopp en artikkel med tittelen «Men die for honor and women die for love». Har dette noe for seg?

- Det tror jeg nok, i hvertfall kan den suicidale prosessen kan være forskjellig. Den kjente depresjonsforskeren Paul Gilbert, som har hatt stor innflytelse på håpløshetspsykologien, undersøkte hva som skjer når mennesker utvikler stor grad av håpløshet. I en type av eksperimenter han giorde satte han to hannfugler sammen i et lite bur. I en slik situasjon vil giennomsnittlige fugler ta opp kampen om herredømmet - kontrollen over reviret. Den fuglen som tapte kampen trakk seg bort, var passiv og viste ellers atferd som hos mennesker ville minne om depresjon. Dersom forskerne fjernet fuglen relativt raskt fra buret og lot den restitueres i et bur for seg selv,

\section{Veldig få selvmordsforebyggingsprogrammer tar hoyde for denne forskjellen mellom menn og kvinner.}

kom den seg raskt. Men hvis den ble tvunget til å være i situasionen mer enn 48 timer, ble det ikke mulige å reversere den nevnte atferden selv om man fjernet fuglen fra buret. Hva skjer i hjernen på en sånn fugl når den blir utsatt for et nederlag og ikke kan slippe unna situasjonen? Vi antar at det som skjer er at hjernens stressresponssystemer blir aktivert og forblir aktivert over lang tid. Dette har vært studert hos mennesker der vi finner at en overaktivert HPA-akse (sentralt ledd i hiernens stress-respons systemer) etter hvert fører til en utslukket stress-respons. Dette har man påvist som en biologisk markør for depresjon. Så dette med å være under sterkt stress og samtidig fanget i situasionen, kan ha stor forklaringsverdi for utvikling av depresion - og håpløshet og dermed suicidalitet. Jeg tror også dette er særlig relevant for å forklare hvordan en del menn blir deprimerte, håpløse og kanskje også suicidale. De har mistet troen på at de kan komme ut av situasjonen på egen hjelp. Og kanskje de har rett når de mener de overhodet ikke kan komme seg ved egen hielp. Det er en farlig tilstand og en viktig tilstand å oppdage for oss som skal hielpe folk som er i krise.

leg tenker på den folelsen og tilstanden - alt er provd og ingenting har nytta, og at man er fastlåst i det samme territoriet. Det er ganske likt som for den fuglen i bur?

- Dette er en nøkkel til å forstå håpløsheten, både for menn og kvinner. Det er få som tar livet sitt fordi de ønsker å dø. De giør det fordi de har det intenst vondt og har mistet håp og tro på at de kan få det bedre. Det er kombinasjon av to ting som ikke er så lett å leve med, å ha det uutholdelig og ikke tro at det blir bedre. Selvmord er en flukt - fra buret om du vil. Men vi ønsker å åpne en annen dør til buret, og hjelpe folk å finne en annen fluktvei enn selvmord.

\section{Er strategien om å åpne dora bedre tilpasset} kvinner enn menn i vår kultur?

- En måte å åpne døra er å snakke seg ut av det; sette ord på det vonde, få hjelp til å se det fra en annen synsvinkel og finne løsninger og utveier. Men terskelen for menn for å delta i snakketerapi er ofte veldig høy. Hvorfor? Antakeligvis fordi mange av de temaene man da kommer inn på er 
lite forenlig med det selvbildet mange menn har av å være selvhiulpen, sterk og uavhengig og som en person som andre setter sin lit til og avhenger av. Å kjenne på hjelpeløshet, avhengighet eller angst kan være så aversivt at en del menn heller vil være dø enn å gå giennom det med en terapeut eller hielper. En hjelper, som la oss være ærlige, ofte er en kvinne. Som terapeut opplever jeg oftere at menn gir uttrykk for at «dette har jeg aldri snakket med noen om før». Men etter min erfaring reagerer menn like positivt på å få hull på vonde ting som kvinner, når de først har giort det.

\section{Likevel er det vanskelig å tenke seg at den store ubalansen i kjønn blant ansatte i barnehager, i småskolen, i barnevern og i barnepsykiatrien ikke skulle ha noen betydning i vår sammenheng.}

\author{
Feminine diskurser \\ I utviklingspsykologien og studier av atferds- \\ problemer hos barn blir det ofte understreket at \\ læreren representerer en feminin diskurs. Det fins \\ teorier om motet mellom skolesystemets femini- \\ serte ramme og guttene, og at resultatet kan bli at \\ guttene oppleves som at de skaper mer problemer. \\ Kan det være at vi i hjelpeapparatet er offer for \\ det samme? \\ - Det kan godt være, men vi har for lite forskning \\ på dette. I en undersøkelse vi giorde for 25 år \\ siden, «Rom for unge liv», lette vi etter forkla- \\ ringer på at det hadde skjedd en så stor økning \\ i selvmordsraten blant unge i Norge, og særlig \\ blant gutter. Noen av guttene sa akkurat dette, at \\ noe av den naturlige atferden deres hadde blitt \\ forklart som problematisk helt fra barnehage \\ og oppover i skolen. De mente at barnehage- og \\ skolepersonalet mente det godt, men at de hadde \\ misforstått. At de hadde unnlatt å anerkjenne \\ reelle kjønnsforskjeller i normativ atferd. Om \\ dette virkelig stemmer, om det er uttrykk for et \\ bredt befolkningsfenomen, det vet ikke jeg - men \\ jeg tror det er for lite forsket på. Jeg har i hvert \\ fall vært borti mange som har sagt dette. Så kan \\ man hevde at det også er mange jenter som kan \\ ha hatt liknende opplevelser av å ikke bli forstått \\ på egne premisser. Likevel er det vanskelig å \\ tenke seg at den store ubalansen i kjønn blant \\ ansatte i barnehager, i småskolen, i barnevern og \\ i barnepsykiatrien ikke skulle ha noen betydning \\ i vår sammenheng. Dette er en utfordring for \\ videre likestilling i Norge.
}

Rart å tenke på, sett med våre øyne, at man så åpenbart har utdefinert mannen.

- Hvis vi skal giøre noe med dette problemet, må vi tenke nytt. Vi må tenke både på hvordan vi kan påvirke samfunsstrukturer som ikke er gode og hvordan vi kan hielpe den enkelte. Vi bør bruke hva vi vet om psykologien i suicidale prosesser til å videreutvikle hielpeapparatet hvordan det responderer. Det er for eksempel et stort paradoks at vi vet at det er ikke så stor forskjell mellom jenter og gutter når det gielder forekomst av villet egenskade, men nesten alle behandlingsstudier, i den vestlige verden i hvertfall, har hovedsakelig behandlet jenter. Det vil si at i de fleste studier har man inkludert ca $10 \%$ gutter og $90 \%$ jenter. Likevel så generaliserer vi - til alle! Denne typen metodisk svakhet blir ofte underkommunisert i vitenskapelige publikasjoner og den blir heller ikke tatt godt nok høyde for når faglige anbefalinger om behandling blir utviklet. Dette er jeg veldig opptatt av at vi må løfte sterkere fram i organisasjoner som jobber med forskning og forebygging! Vårt senter burde også se på det - er det noe vi kan giøre for å utvikle mer forskning som retter seg mot menns suicidalitet? Dette handler jo også om politikk - hva det er vi prioriterer når vi utvikler samfunnet vårt.

\section{Selv forskning har sin politiske agenda?}

- Det er interessant at vi i hvertfall ikke er blitt nevneverdig utfordret på å giøre slike studier. Kiønn er forsømt tematikk.

Skandinavia går for å være den delen av verden hvor likestilling mellom kjønnene er kommet definitiv lengst. En kan jo bli litt pessimistisk når slike forskjeller er tilstede også hos oss. Hva kan vi giore, både som samfunn og som ansatte $i$ psykisk helsevern?

- I øyeblikket arbeider vi med en stor ny satsing på å oppdage depresion ute i befolkningen. Den har som mål å nå ut til de som ikke allerede er i behandling eller hielpeapparat, men som vi vet er der og som ellers ikke blir oppdaget. Dette tror vi er relevant særlig for menn, ikke minst yngre menn. Vi har valgt å gå med i den såkalte European Alliance Against Depression (EAAD) for å samarbeide med andre land i Europa om å nå lenger ut i befolkningen til grupper som ellers ikke nås. I tillegg er det behov for okt satsning på forebyggingsstrategier i skolen og bruk av massemedier for å drive folkeopplysning.

\section{Ulike strategier for å regulere følelser}

Selv om forskjellene ikke er så store, ser vi likevel en høyere forekomst av selvskading blant kvinner 
enn blant menn. Hva tenker du om årsakene til dette?

- Det er nok ikke så stor forskjell i forekomst, men det er muligens også forskjeller i hvordan selvskadingen fungerer. Jeg tror vi burde lete etter ekvivalenter, hva tiener samme funksjon å regulere følelser, uro og stress. Selvskading er veldig sterkt knyttet til mangel på mer konstruktive ferdigheter til å regulere slike følelser.

Hva slags strategier bruker gutter?

- Slåssing, mobbing, vold, utagering, ødeleggelse av ting - det mange vil kalle antisosial atferd, komme i klammeri med kamerater, lærere og foreldre - er ofte uttrykk for destruktive måter å regulere følelser på. Statistikk viser at dette er spesialiteten til gutter. Oftest er det ikke helsevesenet gutter med slik atferd kommer i kontakt med. De kommer oftere til barnevernet og dessverre også til politiet. Heldigvis har barnevernet i Norge, i Region Nord, tatt i bruk strategier hentet fra dialektisk atferdsterapi for å hjelpe ungdommene de kommer i kontakt med å lære å regulere følelser og løse problemer. Og dette arbeidet er i ferd med å spre seg til resten av landet og bli et tverrsektorielt samarbeid mellom barnevern og helsevesen. Jeg tror det er mange gutter som vil få bedre hjelp enn tidligere giennom denne store satsningen.

\section{Beskyttelse av unge liv}

Et mye diskutert forhold er den økningen av selvmord i den yngre aldersgruppen 15-24 år som fant sted $i$ hele vår vestlige kulturkrets (VestEuropa og USA) tidligere. Denne økningen har heldigvis stoppet opp nå - $\mathrm{i}$ alle fall $\mathrm{i}$ Norge og det meste av Europa. Jeg tror grunnen til at vi fikk nasjonale planer i selvmordsforebygging nettopp er okningen man observerte i denne aldersgruppen. Dette er selvmord samfunnet definitivt ikke tåler - at ungdom med livet foran seg velger å dø. Det at denne okningen giorde seg gieldende $i$ hele Vest-Europa og USA giorde at man søkte årsaken i sosiokulturelle variabler, som at rollen som ung mann var blitt vanskeligere, og lignende. Hva tenker du om denne okningen man så blant ungdom for 15-20 år siden?

- Det er vanskelig å trekke sikre slutninger. Men vi tror at en av årsakene til at vi hadde en så sterk økning blant unge gutter (i Norge en femdobling på 20 år) er mange forhold i samfunnet som kunne virke beskyttende endret seg til det negative samtidig som det tilkom nye risikofaktorer. I en stor befolkningsstudie vi utførte for noen år tilbake så vi på 30 variabler i samspill og mange faktorer som spilte inn. Mange faktorer som okte risikoen for selvmord blant unge hand- let om ustabilitet; hvor mange flyttinger ungdommen hadde opplevd under oppveksten, hvor mange samlivsbrudd foreldrene hadde hatt, hvor mange avbrudd i utdannelsen de hadde erfart og hvor mange sykehusinnleggelser og syketilfeller - eksempler på ustabilitet i oppvekstperioden.

leg tenker på Durkheims begrep om anomi, normloshet, opplosning ...

- Ja, det er lett å tenke i slike baner. Selvmordsraten blant unge begynte å stige kraftig fra slutten av 1960-tallet. Før den tid var mange lokalsamfunn i Norge nok kjennetegnet ved stor stabilitet når det gielder unges levekår. Samtidig var det stor forskjell på hvordan unge i storbyene og på landsbygda levde. Dette var et tydelig funn i Nils Johan Laviks studie der urban ungdom levde ganske forskjellige liv enn rural ungdom. På bygda kiente alle hverandre i større eller mindre grad, det var veldig trygt og forutsigbart, men samtidig sikkert også ganske begrensende for mange unge. I byene kunne ungdom i større grad velge forskjellige måter å leve på, men samtidig var de også utsatt for flere risikofaktorer. Før 1970 var selvmord blant unge i Norge et storbyfenomen og lite utbredt i rurale strøk. Skillet mellom by og land når det gielder ungdoms levekår ble utydeligere utover på 7o-tallet blant annet pga. økt mobilitet og økt urbanisering, populærkultur og medier. Samtidig sluttet selvmord blant ungdom å være et byfenomen.

\section{Selvmord blant unge vekker politikere til handling, og vi ville trolig ikke fått våre forste handlingsplaner mot selvmord uten dette.}

Friheten har blitt utvidet, og dermed også usikkerheten, på bekostning av trygge rammer. Dette kan være svimlende identitetsbyggende, hva skal man giøre som menneske med livet sitt - det er klart at det er ganske vanskelig for ungdom med en slik stor frihet. Nasjonale planer for selvmordsforebygging kom vel mye av denne perioden? - Ja, og fortsatt giør det det, også i andre land. Selvmord blant unge vekker politikere til handling, og vi ville trolig ikke fått våre første handlingsplaner mot selvmord uten dette.

\section{Alt handler om hjernen}

Hvordan kan man se forbi kjønnsstereotypiene - men se monstrene?

- Innenfor ethvert mønster fins det en voldsom variasjon, av forståelige grunner, det kan henge sammen med genetisk disposisjon og at forskjellige folk blir eksponert for ulike erfaringer - eller 
miljøfaktorer om du vil. For enkeltmennesker vil det ikke være mulig å la seg definere på de premissene vi har snakket om, selv om vi altså likevel antar at det finnes viktige kjønnsrelaterte faktorer som er relevante for å forstå selvmord og selvskadende atferd. Jeg tror en av de positive tingene med å være forsker er at du alltid tenker: «Stemmer det?». Og du stiller også spørsmålet: «Stemmer det fortsatt?». Det er mulig å tenke seg at virkeligheten og empirien forandrer seg, og at det som er normativt i en tidsepoke kan forandre seg i den neste. Samtidig som visse ting ikke forandrer seg så mye; det biologiske endrer seg mye langsommere. Genene våre forandrer seg, men mye langsommere.

leg tror en av de positive tingene med å være forsker er at du alltid tenker: «Stemmer det?» Og du stiller også spørsmålet: «Stemmer det fortsatt?»

- De biologiske perspektivene på selvmord er i ferd med å bli godt etablert. Jeg pleier å si at alt i bunn og grunn handler om hjernen, selv om vi naturligvis fortsatt trenger mange andre måter å studere og beskrive både selvmord og psykisk uhelse på. Freud antisiperte dette som den nevrolog han var. Han mente ikke at de metapsykologiske konstruktene som han etablerte skulle betraktes som sannheter. De ble etablert som redskaper som giorde det mulig å forstå og behandle psykiske lidelser lenge før vi hadde kunnskaper om hvilke prosesser i hiernen som lå til grunn. Men nå lever vi jo i en tid der vi har langt flere redskaper til å studere hva som faktisk skjer i hjernen i helse og sykdom. I dag er det mulig å observere endringer i visse hjerneregioner involvert i følelsesregulering etter at man har gitt behandling som nettopp har som mål å øke pasientens evne til slik regulering. Flere studier har vist at Dialektisk atferdsterapi har effekt på frontal-lappenes evne til å dempe aktiviteten i amygdala i forhold til alarm- og arousal-responser. 